\title{
C-X-C Motif Chemokine 5
}

National Cancer Institute

\section{Source}

National Cancer Institute. C-X-CMotif Chemokine 5. NCI Thesaurus. Code C20470.

C-X-C motif chemokine 5 (114 aa, $\sim 12 \mathrm{kDa}$ ) is encoded by the human CXCL5 gene. This protein is involved in both chemotaxis and activation of neutrophils. 